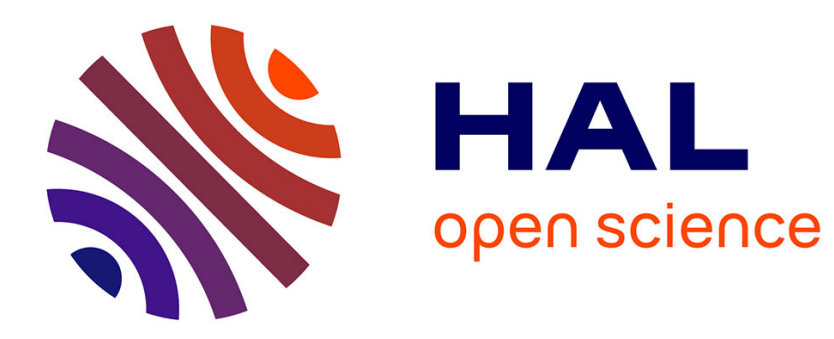

\title{
Applying Spatial Economics to National Spatial Planning
}

J. Peter Clinch, Eoin O’Neill

\section{To cite this version:}

J. Peter Clinch, Eoin O’Neill. Applying Spatial Economics to National Spatial Planning. Regional Studies, 2009, 43 (02), pp.157-178. 10.1080/00343400701808873 . hal-00516182

\section{HAL Id: hal-00516182 \\ https://hal.science/hal-00516182}

Submitted on 9 Sep 2010

HAL is a multi-disciplinary open access archive for the deposit and dissemination of scientific research documents, whether they are published or not. The documents may come from teaching and research institutions in France or abroad, or from public or private research centers.
L'archive ouverte pluridisciplinaire HAL, est destinée au dépôt et à la diffusion de documents scientifiques de niveau recherche, publiés ou non, émanant des établissements d'enseignement et de recherche français ou étrangers, des laboratoires publics ou privés. 


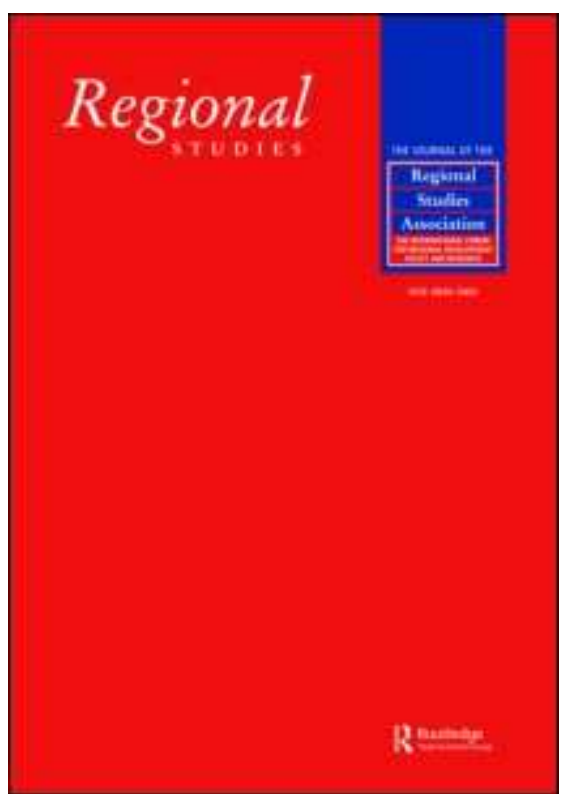

\section{Applying Spatial Economics to National Spatial Planning}

\begin{tabular}{|r|l|}
\hline Journal: & Regional Studies \\
\hline Manuscript ID: & CRES-2006-0267.R2 \\
\hline Manuscript Type: & Main Section \\
\hline JEL codes: & $\begin{array}{l}\text { R12 - Size and Spatial Distributions of Regional Economic Activity < } \\
\text { R1 - General Regional Economics < R - Urban, Rural, and Regional } \\
\text { Economics, R14 - Land Use Patterns < R1 - General Regional } \\
\text { Economics < R - Urban, Rural, and Regional Economics, R52 - Land } \\
\text { Use and Other Regulations < R5 - Regional Government Analysis < } \\
\text { R - Urban, Rural, and Regional Economics, R58 - Regional } \\
\text { Development Policy < R5 - Regional Government Analysis < R - } \\
\text { Urban, Rural, and Regional Economics }\end{array}$ \\
\hline Keywords: & $\begin{array}{l}\text { Spatial Economics, New Economic Geography, National Spatial } \\
\text { Planning, Spatial Policy, Ireland, Regional Policy }\end{array}$ \\
\hline
\end{tabular}

\section{SCHOLARONE}

Manuscripts 


\title{
Applying Spatial Economics to National Spatial Planning
}

\author{
J. Peter Clinch and Eoin O'Neill \\ University College Dublin
}

J. Peter Clinch (corresponding author), Planning and Environmental Policy, University College Dublin, Richview, Clonskeagh, Dublin 14, Ireland. Email: peter.clinch@ucd.ie

Eoin O’Neill, Planning and Environmental Policy, University College Dublin, Richview, Clonskeagh, Dublin 14, Ireland. Email: eoin.oneill@ucd.ie

First: November 2006. Accepted: June 2007

\begin{abstract}
Despite the impressive development of the field of spatial economics, some have criticised the lack of policy applications. In addition, the literature has not yet identified the relevance of new economic geography, and spatial economics generally, for national spatial planning. This is surprising considering the interest in spatial planning policy in Europe. By combining old theories of trade and space with new economic geography, this paper applies spatial economics to national spatial planning and examines a case study of Ireland. The paper suggests that spatial economics provides a useful theoretical framework for the analysis of national spatial planning policy but suffers from deficiencies in respect of its consideration of social and environmental aspects of planning and development.
\end{abstract}

Keywords: Spatial Economics, New Economic Geography, National Spatial Planning, Spatial Policy, Regional Policy, Ireland

Appliquer l'économie géographique à l'aménagement du territoire. 
En dépit du progrès impressionnant de l'économie géographique, certains ont commenté le manque d'applications de politique. En outre, la documentation n'a pas encore identifié l'importance pour l'aménagement du territotoire ni de la nouvelle géographie économique, ni de l'économie géographique en général,. Cela est à surprendre étant donné l'intérêt porté à l'aménagement du territoire en Europe. Alliant les théories reçues à propos du commerce et de la géographie avec la nouvelle géographie économique, cet article cherche à appliquer l'économie géographique à l'aménagement du territoire et examine l'Irlande comme étude de cas. L'article laisse supposer que l'économie géographique fournit un cadre théorique utile pour analyser l'aménagement du territoire mais manque de considération des aspects sociaux et environnementaux de la planification et du développement.

Economie géographique / Nouvelle géographie économique / Aménagement du territoire / Politique géographique / Politique régionale / Irlande

\section{Anwendung der Raumökonomie auf die nationale Raumplanung J. Peter Clinch and Eoin O'Neill}

Trotz der beeindruckenden Entwicklungen im Gebiet der Raumökonomie wird gelegentlich eine Kritik am Mangel an politischen Anwendungen laut. Hinzu kommt, dass die Relevanz der neuen Wirtschaftsgeografie und der Raumökonomie im Allgemeinen für eine nationale Raumplanung in der Literatur noch nicht identifiziert wurde. Angesichts des Interesses für Raumplanungspolitik in Europa ist dies überraschend. In diesem Aufsatz wird die Raumökonomie durch eine Kombination der alten Theorien von Handel und Raum mit der neuen Wirtschaftsgeografie auf die nationale Raumplanung angewandt, wobei eine Fallstudie in Irland untersucht wird. Wir stellen die These auf, dass die Raumökonomie einen nützlichen theoretischen Rahmen zur Analyse der nationalen Raumplanungspolitik bietet, aber an Mängeln leidet, was die Berücksichtigung von Gesellschaftsund Umweltaspekten der Planung und Entwicklung anbelangt.

\section{Keywords:}

Raumökonomie

Neue Wirtschaftsgeografie

Nationale Raumplanung

Raumpolitik

Regionalpolitik

Irland

R12, R14, R52, R58

Aplicación de la economía espacial a la planificación espacial nacional

\section{$\underline{\text { J. Peter Clinch and Eoin O’Neill }}$}

Pese al impresionante desarrollo en el campo de la economía espacial, se ha criticado la falta de aplicaciones políticas. Asimismo la literatura todavía no ha identificado la importancia de la nueva geografía económica, y de la economía espacial en general, para la planificación espacial a nivel nacional. Esto resulta sorprendente si consideramos el interés en la política de planificación espacial en Europa. Combinando las antiguas teorías de comercio y espacio con la nueva geografía económica, en este artículo aplicamos la economía espacial a la planificación espacial a 
nivel nacional y examinamos un caso práctico de Irlanda. Aquí sugerimos que la economía espacial ofrece una estructura teórica útil para el análisis de la política en la planificación espacial nacional pero adolece de deficiencias con respecto a su consideración de aspectos sociales y medioambientales en la planificación y el desarrollo.

\section{Keywords:}

Economía espacial

Nueva geografía económica

Planificación espacial nacional

Política espacial

Política regional

Irlanda

R12, R14, R52, R58 


\subsection{Introduction}

The potential applications of spatial economic analysis to policy are increasingly being recognised by economists and economic geographers. A large literature related to spatial economic analysis emerged during the course of the $20^{\text {th }}$ century. During the course of the 1990s, economists (re)discovered 'geography' (Martin, 1999a) leading to the development of 'New Economic Geography' (NEG) and the advancement of spatial economic analysis. They built on earlier approaches to economics and geography from models that were originally developed within the fields of regional development theory, urban economics, regional science and economic geography (for a review, see, for example, Friedmann, 2001; Isserman, 1995; McCann, 2001).

NEG, as the latest component of spatial economic analysis has, to date, concentrated on developing a theoretical framework and mathematical models of spatial development based on new trade theory ${ }^{1}$. Traditional economic geography was modelled on constant returns to scale, perfect competition and comparative advantage (Krugman, 1998b). Krugman explains the technical advances that distinguish NEG from traditional economic geography ${ }^{2}$, in particular the technical advances that facilitate modelling of imperfect competition and increasing returns to scale (this is the key distinction), thereby giving status to geographical advantage in economic analysis. Concepts used by economic geography, such as historical accident and cumulative causation (Myrdal, 1957), backwards and forwards linkages (Hirschman, 1958) and core-periphery (Friedmann, 1966) are also adapted into this new model of spatial analysis, as are the early works of Marshall (1920). Krugman (1998a, 1998b, 1999) describes the distinctive aspects and modelling principles of NEG, including increasing returns to scale, and applies these principles to analysis of the influence of transportation and the 'hub effect' on urban concentration (Krugman, 1993, 1996). Fujita and Mori (1996) develop this further, examining the role of ports in the making of major cities. Venables (1996) and Krugman and Venables (1996) apply the principles and models of NEG to the analysis of industrial location and agglomeration, whilst Krugman (1993) and Fujita et al. (1999) examine cities as a component of urban systems and as units of international trade. The specific influence of international trade on industrial location according to NEG principles is explained by a number of authors (see for example, Venables, 1998; Ricci, 1999; Krugman and Venables, 1996) as is inequality between nations (see for example, Krugman and Venables, 1995; Krugman and Elizondo, 1995). Some have identified the implications of international trade for regional policy at a supra-national level (see for example, Ottaviano 2003; Puga, 1999).

Despite the impressive development of this literature in recent years, existing academic literature has not yet identified the relevance of NEG or spatial economics to national spatial planning, and consequently this potential evidence base for policy remains largely unexplored. Davoudi and Wishardt (2003) and Wong (2002), are the rare exceptions to the limited amount of peer-reviewed academic literature as regards national spatial planning. This is surprising given the interest in policy in Europe, for example, the National Spatial Strategy for Ireland, the Regional Development Strategy for Northern Ireland, the Wales 
Spatial Plan, the Spatial Planning Framework for Scotland, the Fifth National Policy Document on Spatial Planning for the Netherlands, and the National Spatial Planning Reports for Denmark ${ }^{3}$. The spatial economics literature has largely concentrated on developing theoretical principles as a foundation for empirical analysis of market forces over space. However, there is increasing criticism of the failure of NEG to apply this analysis beyond a theoretical or abstract scale, or to develop applications to public policy (Fujita et al., 2001; Fujita and Krugman, 2004; Neary, 2001, 2006). This is also illustrated by the lack of a clear theoretical framework or spatial economic analysis in many of the public policy documents on spatial planning.

Whilst recent contributions from economics, in particular regional economics, provide a theoretical basis for economic analysis of international trade (Armstrong and Taylor, 2000), mainstream economics traditionally neglected spatial analysis of economies or market forces. The spatial economic analysis literature, in particular that contributed to by NEG, has tended to focus on the nation, a supra-national region, as the unit of regional analysis for international trade, with much of its focus on theoretical analysis and modelling. However there are substantial differences in economic performance within nations and across sub-national regions, requiring more detailed analysis at a sub-national scale. Furthermore, the regional implications of investment in national transportation routes also requires more detailed analysis in the context of national spatial planning.

In a review piece on NEG and book review of Fujita et al. (2001), Neary (2001, 2006), whilst identifying the positive contribution of this literature, highlights some additional problems of NEG, including the failure to specify the spatial unit of analysis and the lack of empirical work and case studies to identify the appropriate level of spatial analysis. Interestingly he identifies the need to further integrate the NEG theories with the knowledge of the older theories, and finally, the need to improve identification of policy implications beyond the basic 'agglomeration is unambiguously good for you' (Neary, 2001:556). Martin (1999a, 1999b) and Scott (2004) similarly identify the failure of NEG literature to identify empirical applications.

A Spatial Economic Theory, building on the well-established theories from geography, trade and space theory ${ }^{4}$ and theoretical advances of NEG, may provide a suitable theoretical basis for national spatial planning ${ }^{5}$ and offer valuable lessons to policy makers. This paper specifically seeks to further the spatial economics literature by highlighting the potential policy applications to national spatial planning. In order to do this it firstly seeks to apply a combined spatial economic theory and analysis to national spatial planning. A second objective is to provide, by way of an Irish example, a methodology for analysis of national spatial planning policies.

\subsection{Methodology}


The methodology used in this paper involves the development of a theoretical basis for national spatial planning and then an analysis of the theory using a case study. This is achieved using the following methodological approach: firstly, outlining the theoretical rationale for national spatial planning through welfare economics; secondly, mobilising and further enhancing the tools of economic analysis relevant to national spatial planning generated by trade and space theories, and providing a method through which national spatial planning policies can be evaluated; thirdly, applying these tools of spatial economic theory and analysis to a case study of Ireland; and fourthly, evaluating the application of spatial economic theory to national spatial planning.

\subsection{Welfare Economics: the Rationale for National Spatial Planning}

The basic theorems of welfare economics provide the rationale for government intervention where the market fails. The economic rationale for planning and national spatial planning is derived from the concept of market failure based on the theories of welfare economics. Welfare economics in a planning context is concerned with societal quality of life. Where land-use externalities or regional disparities exist and have important spatial or regional significance, there may be a market failure that would require intervention in the public interest.

The usually cited cause of such regional disparities is the lack of mechanisms to ensure the benefits of growth and development are evenly distributed or dispersed across regions, leading to a disproportionate development of the centre or core. This may result in subsequent market failures such as congestion externalities (traffic and population) and lack of job opportunities. Labour-market rigidities and restrictions on the movement of labour may result in higher levels of unemployment in certain areas. Such market failures can justify intervention in the market. At the level of a nation state, national spatial planning may be used in an attempt to change the distribution of population and economic activity from what would occur without intervention. It is important to point out that the presence of differing income levels across a nation is not necessarily an indicator of market failure. Rather than income, the focus should be on quality of life more generally. One would expect that, if markets work correctly, areas with lower environmental quality (e.g. a congested urban area) would have higher income levels. Therefore, if a policy objective is to equalize the well-being of individuals, the objective of 'balanced regional development', if it is taken to mean (as it often is in a political arena) the equalization of individual or household income across space, would be inappropriate unless other variables that influence quality of life were also equalized. Nevertheless, for spatial planning to be effective and to develop appropriate policy instruments to address disparities where appropriate, it is necessary to understand the drivers of existing spatial distributions and this is where spatial economics provides some potential.

\subsection{Applying Spatial Economic Theory to National Spatial Planning}


The most recent advance in spatial economics, namely NEG, has tended to focus on abstract spatial models, and units of regional analysis relevant to international trade. The distinctive attribute of this paper is that it takes those elements of NEG and old spatial economic analysis that are most relevant to the sub-national level and national spatial planning context. Although NEG pays attention to the issue of historical accident and centralisation we apply greater significance to these issues at a national scale. We further advance these theories by emphasising the importance of the issues of power relations, in particular emphasising that the policymaking process in planning is inherently political (see section 4.2), and also the important role that path-dependence plays in determining the spatial structure of national economies in the long-run (see section 3.1). The methodology used to evaluate spatial patterns and spatial policy interventions is based on the use of a number of modelling themes at a national scale, Core and Periphery; Urban Concentration - Trade and Power Relations; Transportation and Regions, (adapted from Krugman, 1991, 1996, 1998a, 1998b, 1999). Using relevant data on the spatial distribution of socio-economics characteristics relevant to quality of life, these modelling themes provide a framework to explain current trends. Furthermore, by predicting spatial patterns consequent on national spatial policy interventions, we suggest that this theory can assist in policy evaluation.

\subsection{Irish Case Study: Data Collection and GIS}

Over the last decade Ireland has experienced a rapid rate of sustained economic growth during "the Celtic Tiger" era ${ }^{6}$. This period has been associated with considerable regional shifts of both population and economic activity. Consequently, in an attempt to encourage 'balanced regional development' the government introduced a national spatial planning policy - the National Spatial Strategy (NSS) - and later a job relocation programme (Decentralisation) to decentralise public jobs to provincial locations (see section 5.0). This makes Ireland an ideal case study to examine the potential of spatial economic theory to explain national trends regarding population and economic activity, and also evaluate policy interventions.

In order to undertake this case study, data on the socio-economic characteristics relevant to the spatial distribution of quality of life consistent with those sources of information used in the preparation of the NSS and Decentralisation programme and the modelling themes of Spatial Economic Theory were identified. This dataset includes: 2002 national census data pertaining to all attributes of population and income (from CSO, 2002); transport data relating to regional air routes (from DKM, 2003) and rail passenger levels (from Goodbody, 2000), average annual daily traffic counts on national roads (from National Roads Authority, 2004), data on port freight (from Central Statistics Office, 2003), and all information pertaining to the Decentralistion programme (from Department of Finance, 2003). These data were then merged with detailed geographical information and matched spatially to a map of Ireland using Geographical Information Systems (GIS). GIS is a computer software tool that facilitates the linking of datasets using common spatial identifiers and the visual representation of spatially referenced data in twodimensional space (Goodchild and Haining, 2004; Bond and Devine, 1991; Wu et al., 2001). The spatial presentation of this data facilitated an analysis of existing spatial development patterns (see section 4.0) and 
then an assessment of the ability of national spatial planning intervention to alter those development patterns (see section 5.0 and 6.0). It also assisted in the evaluation of the validity of the model as a theoretical basis for national spatial planning by facilitating an analysis of the consistency of the predictions of the model with the national spatial patterns of development (see sections 6.0 and 7.0).

This next section of this paper examines the context for national spatial planning by taking the literature on NEG, and developing a spatial economic theory relevant to national spatial planning. The fourth section of this paper applies this spatial economic theory to a case study, namely the drivers of the spatial development of Ireland in the absence of policy intervention. The fifth section undertakes an assessment of the potential of the Irish National Spatial Strategy (NSS) and Decentralisation Programme to achieve their stated policy objectives of balanced regional development within Ireland. The final section provides conclusions.

\subsection{National Spatial Planning and Spatial Economic Analysis}

Spatial economic theory seeks to identify what spatial equilibria might exist where the spatial structure emerges from processes guided by the 'invisible hand' of the market (Krugman, 1998b). The concept of equilibrium, both in its general economic application and in its spatial context, is important. Equilibrium is a situation in which supply and demand are in balance. In a geographical context, Goodall (1987) defines equilibrium as a theoretical state of balance with respect to both its internal balance and its external relationships, unyielding over time unless there is a change in one of the controlling or dependant forces. Spatial economic equilibrium is also about opposing market forces. Two pertinent questions, adapted from Krugman et al. (2001) that are key to understanding spatial equilibrium at any scale and therefore applicable to national-level planning and policy, are:

1. What conditions will ensure that the existing number and distribution of urban centres in a nation will be sustained over time?

2. What changes in conditions will ensure that the existing number and distribution of urban centres in a nation will be broken over time?

Small quantitative changes in the balance of market forces can induce major qualitative changes in the pattern of spatial development (Krugman, 1999, 2001). Therefore, small interventions, via spatial planning, can potentially alter growth paths, and be reinforced thereafter through cumulative processes. Leaning heavily on the underlying theories of NEG, what spatial economic theory is seeking to determine is 'the break point' (threshold level) or the conditions under which a new spatial pattern may develop, and 'the sustain point' or the conditions under which it will develop. 
Consequent on the emergence of a spatial pattern of development, spatial economics seeks to analyse whether such a spatial pattern is sustainable. These concepts can be reconciled with analysis of national spatial planning using NEG analytical modelling themes: does a core-periphery model describe the existing spatial economy or do existing trends or policies suggest the development of such a spatial economy, and what are the national spatial implications; do the economic determinants of a sustainable city and region exist, or is intervention required to improve city formation; and, how, when or where should intervention be undertaken. The importance of the role of transportation is highlighted in particular, both as a constraint and as a stimulus to regional development and city formation in spatial economic models. The impacts of free trade and power relations are also important.

\subsection{Factors Underlying the Spatial Distribution of Population and Economic Activity}

The basis for the generation of theories of spatial economic analysis is the observed concentration of economic activity in geographic space. Krugman built upon the ideas of Perroux, such as 'centripetal' and 'centrifugal' forces that promote or inhibit geographic concentration (Table 1). Krugman (1991b) describes centripetal forces as linkages or market size effects, thick labour markets and (pure) external economies; and, centrifugal forces as immobile factors, land rents and pure external diseconomies. Ottaviano (2003) details how the interaction of forward and backward linkages can induce a cycle of agglomeration. He also suggests, as does Baldwin et al. (2003), that the degree of free trade also has spatial consequences promoting agglomeration or dispersal.

\section{Table 1. About here}

NEG and, by extension, modern spatial economic models, select only one element from each of the centripetal and centrifugal forces, namely linkages and immobile factors as the most suitable elements for modelling as both are influenced by transport costs and connected by physical distance and modelling (Krugman 1998b, 1999). There are a number of other key features of spatial economics that build upon the ideas of NEG:

Historical accidents, natural geographical advantages and random events are key determinants of the formation of most cities and the localisation of industry in certain locations (Fujita and Mori, 1996). Selfreinforcing characteristics, once established, persist with a 'lock-in' effect that lead to 'circular causation' or 'self-reinforcing agglomerations' (Krugman, 1999). These also support the concept of 'first-mover advantage' where he who first captures a particular market and establishes himself in that position e.g. a primate city, tends to 'stay ahead' and benefit from a 'lock-in' effect. First movers tend to be difficult to 'dispossess' in terms of a redistribution of population and economic activity, thereby creating a long-run 'path dependence'. This is especially important where there are multiple long-run outcomes, and therefore a single transitory shock may have permanent effects favouring certain outcomes over others (Ottaviano, 2003). 
Ottaviano (2003) points out, however, that the 'break point' of policy intervention renders marginal policy changes ineffective unless the cumulative effect crosses a critical 'break point' where the impact may bring about a new 'catastrophic' spatial outcome. Sometimes the 'break point' threshold may be very large. Davis and Weinstein (2002) found that there is a great deal more stability in the spatial structure of economies explained by simple geographical advantages, path dependence, and cumulative causation, and that long-run city size is robust even to large temporary shocks ${ }^{6}$. This may also be reinforced by the political nature of decision making in planning, and also through the centralisation of power in the dominant core. Davis and Weinstein (2002) also found that increasing returns to scale an important determinant of the degree of spatial differentiation between locations.

One of the main differences between the traditional spatial economic literature and the new spatial economic literature is the application of increasing returns to scale to spatial models. With constant or nonincreasing returns, it would be desirable for every firm to locate its activities equally amongst locations to meet local demand, with production mirroring consumption at a local level (at its simplest, transport does not matter). However, with increasing returns it is more profitable to concentrate production in order to take advantage of agglomeration and specialisation effects. For example, when transportation costs between regions are reducing due to investment in inter-regional transportation infrastructure and transport technology, there are increasing returns to scale which reduce average costs per unit to an individual firm and create agglomeration economies at 'transportation-hub' locations. Increasing returns in terms of transportation are central to the development of spatial economic models and distinguish it from the traditional theories of geography, trade and space.

The following section applies a number of modelling themes, advanced by NEG, to spatial planning at a national scale using a case study of Ireland. These themes (adapted from Krugman, 1991, 1996, 1998a, 1998b, 1999): Core and Periphery; Urban Concentration - Trade and Power Relations; Transportation and Regions, can assist in the analysis of spatial development patterns and trends and, can provide a theoretical basis for the analysis of national spatial planning policies and thereby help inform policy making.

\subsection{Spatial Economic Analysis of Development Patterns in Ireland}

Ireland has recorded rapid economic growth in recent years, particularly during the economic boom from 1996 to 2001 known as "the Celtic Tiger". This rapid growth was unplanned in a national perspective and there is a concern on behalf of government that it is imbalanced with regard to income and population, although some authors such as Walsh (2006) have disputed claims that there are significant regional disparities in per capita disposable income and employment.

The development and publication of the National Spatial Strategy (NSS) by the Irish government was the principal coordinated initiative to promote balanced regional development (Government of Ireland, 2002) ${ }^{7}$ 
Its approach was to develop, at a regional level, urban growth centres or 'engines of growth' known as Gateways and Hubs, and to identify a national transportation framework to link and stimulate the development of these centres ${ }^{8}$. In addition, with the expressed aim of furthering the delivery of balanced regional development, the Irish Government has embarked on a programme of decentralisation of certain government ministries and state agencies to regional locations. Both the NSS and the decentralisation policies have been highly controversial. Controversy inevitably focused on the basis for selection and exclusion of certain urban centres, development of a radial national transportation system, the existing and future role of Dublin in the national urban system, and the generation of sufficient critical mass in the urban growth centres. In addition to these controversies, more recently Irish economists have begun to question whether significant regional disparities still exist (see, for example, Walsh, 2006). In essence, questions have been raised over whether these policies offer a successful means to achieve the government's stated objectives; to develop the full potential of each area to contribute to the optimal performance of the State as a whole - economically, socially and environmentally, and also, to deliver more balanced social, economic and physical development between regions (Government of Ireland, 2002). Prior to undertaking an analysis of whether the NSS and Decentralisation Programme will achieve their stated objectives using spatial economic theory, it is necessary to examine the basis for current spatial development patterns at the national level ${ }^{9}$. Spatial economics provides a set of tools for such an analysis.

\subsection{Core and Periphery}

A number of socio-economic analyses of Ireland show core-periphery patterns in Irish development. Following the approach of Boyle et al. (1999), this shows regional disparities based on measures of Gross Value Added (GVAs) per capita ${ }^{10}$. However, the explanation for the substantial income variation between the regions is productivity differentials arising from both differences in sectoral productivity levels and also in the sectoral distribution of employment.

The principal sources of this inter-regional variation are the industry and services sectors where there are substantial variations in productivity between the regions. Boyle et al. (1999) and DoELG (2000) confirm that almost all the increases in GVA per worker have been derived from industry and services activities located in urban centres and that these productivity differences are attributable to the degree of urbanisation of the regions and the preference for MNCs, to locate in such urban centres ${ }^{11}$. These economic activities have profound effects on the spatial development of Ireland both in terms of urban development patterns and population growth and location.

However Walsh (2006) suggests that disposable income portrays a more accurate indication of economic welfare, as it does not consider the contribution of MNCs to regional economies. There is much less dispersal when disposable income measures are considered. Between the poorest and richest regions nominal disposable income varies between $90 \%$ and $113 \%$ of the average, respectively. If cost of living were included, the real disposable income gap would be smaller. Following the decade long and sustained 
economic growth, there is significantly less regional disparity in Ireland. Walsh, in his analysis of labour market adjustments in the Irish regions, finds that there has been a convergence in unemployment rates with regional differentials weakened, relatively uniform increases in labour force participation rates, and a strong association between national growth and that of smaller regions. Nevertheless, at policy level, the concern seems to be with the spatial distribution of total income rather than per capita income and, indeed, as stated previously, income differentials at a spatial scale do not necessarily justify policy intervention. Figure 1a shows the national distribution of disposable income by county with highest income measures, on average, found in the Greater Dublin Area (GDA) and Mid-East region. Figure 1b shows disposable income density per county and finds similar spatial concentrations around the Dublin commuter belt.

\section{Figure 1. About here}

Ireland now has a population of 4.1 million of which approximately 1.5 million or nearly $40 \%$ live in the GDA (CSO, 2005). The existing urban structure and settlement pattern is perceived by Walsh, J. (2000) and Boyle et al. (1999) as 'particularly weak'. Dublin is over five times the size of Cork and only three other settlements have a population over 40,000 . Figure $1 \mathrm{~b}$ shows the national population distribution by county.

Dublin's dominance can be explained as the result of historical accident, its coastal port location (transport hub) and first mover advantage as the second city in the then British Empire. The continuous development and dominance of Dublin is due to both historical accident and path dependence (Walsh, B.M., 2000). Based on current trends, it is predicted that without policy intervention up to four fifths of the state population growth could take place in and around the GDA over the next 20 years (Government of Ireland, 2002). Figure $1 \mathrm{c}$ and $1 \mathrm{~d}$ show the existing population density and population growth rates by county.

There has been a rapid and relatively unplanned increase in residential development around urban centres and in parts of the GDA and the Dublin hinterland, resulting in a large commuter belt (Gkartzios and Scott, 2005). This type of commuter development is to be seen emerging along the major routes around all the major urban centres but it is most profound in the GDA and Dublin commuter belt and has negative environmental and social effects. These external effects can, however, be captured in terms of overall measures of quality of life. Clinch et al. (2007), using a standard life satisfaction measure, found that there are significant regional disparities in terms of quality of life within Ireland, in particular relating to localised environmental quality and life satisfaction. More specifically it was found that measurements of life satisfaction of those living in Dublin (the core) were lower than all other areas outside of Dublin due to traffic congestion, lower environmental quality, and congested access to services compared to those living in other regional cities, large and small towns and rural areas. 
Based on this analysis a core-periphery development pattern persists, with the Greater Dublin Area and Mid-East clearly comprising the core, and the remainder of the country comprising the periphery as portrayed in Figure 1.

\subsection{Urban Concentration - Trade and Power Relations}

Consistent with spatial economic theory, political centralisation in Dublin and the consequent impact of regional multiplier effects create opportunities for further cumulative causation, concentration of economic activity and population, and a persistence of regional imbalance.

All significant policy decisions are made or at least 'rubber stamped' in Dublin, which hosts the seat of government ${ }^{12}$. Government creates direct demand for labour and services and there are also perceived benefits from access and closeness to the centre due to the concentration of 'lobbyists' and improved access to decision makers. The result of this centralisation of power is that all major Irish media outlets, employer and industry representatives (including the major farming union), employee representative organisations and political parties are headquartered in Dublin (Davoudi and Wishardt, 2005). We place greater emphasis on the issue of power than previous theories as without devolution of power to the regions and changes to governance structures there is unlikely to be a break in the path dependence of the national urban system. The policymaking process in planning is inherently political and tends to favour the dominant core. In terms of policy outcomes, there is some evidence to support this proposition. The midterm review of the National Development Plan 2000 - 2006 (NDP) in 2003, showed proportionately more of the national tax-take spent on key infrastructure was spent in the core with 77\% of the NDP (Economic and Social Infrastructure Operational Programme) invested in the South and East Region (includes the Greater Dublin Area) compared with the BMW Region ${ }^{13}$ which contains the most peripheral regions of the country (Indecon International Economic Consultants, 2003). While there has been small government programmes previously decentralising parts of the public service to the regions, there has been no regional devolution of decision making or power.

According to spatial economics, free and open trade has two major effects on urban concentration. Where there is a high level of free trade with decentralisation and regional devolution of power, it tends to result in a smaller central city with the exception of countries with a small population, where the result is a concentration of population in a primate city (Krugman, 1996). Ireland, being a country with a small population, and acclaiming itself as one of the most open, free-trade economies in the world would therefore be an obvious candidate for a country dominated by a primate city, as is the case with Dublin. This effect is further substantiated by Walsh, B.M. (2000) who identifies a 'Dublin effect' whereby the GDA has grown far faster than would have been be expected based on its initial high level of urbanisation and low dependency on agriculture, and also suggests that this corresponds to the tendency for countries with late industrial development to develop with a primate city. 


\subsection{Transportation and Regions}

Transportation acts as a constraint and as a stimulus to regional development and city formation in spatial economic models. Investment in national transportation infrastructure creates beneficial effects in spreading economic benefits throughout the regions but a transportation system that centres on a single city will ultimately reinforce its dominance (Krugman, 1996). The entire transportation system in Ireland is a radial one consisting of road, rail, and airports links each with Dublin as the hub.

Dublin is the national air transportation hub in terms of passenger numbers, with $75 \%$ of all Irish air passengers compared to the next highest at Shannon with 10\% of air passengers (Figure 2a). All interregional air routes within Ireland including Public Service Obligation (PSO) and Commercial (Comm.) routes area are centred on Dublin, with one exception, namely Cork-Belfast (Figure 2b). In terms of seabased transport, $60 \%$ of all sea passengers come through the Dublin ports of Dublin and Dun Laoghaire and $65 \%$ of total cargo related traffic (Figure 3a).

Figure 2. About here

Figure 3. About here

In terms of rail transportation, Goodbody Economic Consultants (2000) found that of the total 10.6 million passenger rail journeys in Ireland, 59\% of those were to or from Dublin. In addition Dublin appears as an origin or destination in the top ten national county-to-county rail movements. Figure $3 b$ shows that the inter-regional rail system is a Dublin-orientated system. Similarly the national road network is a radial system that converges on Dublin as illustrated in Figure 4a, which identifies the National Primary Road Network and shows the average annual daily traffic (AADT) flow on each national road section. Roads, both national and non-national, are the primary mode of internal transport in Ireland, accounting for $96 \%$ of passenger traffic and 93\% of freight transport (NRA, 2003). At present, of the total 200km (approx. to date) of existing motorway standard national primary route-way in Ireland, 65\% is located in the GDA on national primary roads to and from Dublin and all other motorway standard road in Ireland are extensions of these national primary roads to Dublin and primarily located in counties bordering the GDA. Whilst having greater regional spread, dual carriageway roads also (approx. $300 \mathrm{~km}$ to date) comprise of national primary routes largely to and from Dublin.

Figure 4. About here

Whilst there is major traffic congestion on certain points along the routeways, in particular around the GDA, for example an AADT of 100,000 on M50 Dublin ringroad, there is a relatively small quantity of inter-regional traffic. Goodbody Economic Consultants (2000) estimated that there are approximately 1,500 daily origin-destination trips between Dublin and the other regional cities. The development of a 
national inter-urban motorway network has been suggested as a means to improve linkages between urban centres.

Self-reinforcing advantages of market access tend to be accentuated in regional cities by the neglect of the national transport network (Krugman, 1996) and/or by the centering of the transport network on a primate city (and national transport hub) (Krugman, 1999). Currently all transport linkages primarily focus on Dublin, the administrative and economic capital of the island. All the main road and rail networks are centred on Dublin, which benefits from the 'hub effect' and superior market access, therefore firms benefiting from economic of scale will prefer to locate in Dublin.

\subsection{Policy Intervention: National Spatial Strategy and Decentralisation Programme}

The Irish national economy exhibits many of the characteristics of a core-periphery spatial economy, namely: an uneven distribution of population and total income, a politically dominant and primate capital city, and a radial transportation network (Krugman, 1996, 1999). This is the consequence of the rapid growth of Dublin as the core with no counterweight on the rest of the island. However, this national core dominance is now perceived by some to be having a negative impact on the regional balance of the national economy in terms of the distribution of population and economic activity, and environmental quality, with resultant regional disparities in terms of quality of life (see for example: O'Leary, 2002; O'Leary, 2003; Convery et al., 2006).

The persistence of a core-periphery economy has encouraged the Irish Government to adopt spatial policy intervention in an attempt to influence development patterns and promote balanced regional development within Ireland.

An established core-periphery pattern of development can be very difficult to reverse. In fact, market forces and perverse policy interventions may reinforce a core-periphery economy (Krugman, 1999). Policy interventions, based on what spatial economics suggests, present the main lessons relevant to national spatial planning policy. Intervention must therefore be carefully managed and the spatial implications fully assessed prior to implementation. In general a 'laissez faire' policy will eventually result in regional city formation with a 'break point' (threshold) ultimately being achieved through population growth over the long run (Fujita and Mori, 1996). However, as previously noted, spatial economic theory can contribute to national spatial policy by providing the tools to determine 'the sustain point' and 'the break point' conditions under which spatial patterns develop. Previous analysis suggested that by restricting the development of the main primate city, regional city growth may be stimulated earlier. In particular, the role of transportation networks and linkages are highlighted by spatial economic models of city formation (Krugman, 1996). 
Adapting spatial economics and applying it to national spatial planning in Ireland, the theory would suggest that the timing of regional city formation may be influenced by temporarily restraining the continued outward expansion of the Dublin core and thereby stimulating the market potential of the regions. By building critical mass in these regional locations, the potential of regional locations may then have the capacity to cross a critical threshold or 'break point'. This change in market forces would result in an unstable spatial equilibrium to which the spatial economy may respond and seek a new spatial equilibrium through a variety of mechanisms and patterns. Ultimately this may create the initial advantage necessary for city formation or city development.

The Irish government has introduced the NSS to intervene in the national spatial economy and try to promote 'balanced regional development'. In order to achieve this objective the theory would suggest that national spatial planning intervention should select a limited number of locations for urban growth and investment in order to maximise critical mass and returns to scale and ensure that a national transportation network develops inter-regional linkages rather than reinforcing the dominance of the Dublin hub. The question arises as to whether the NSS will successfully bring about 'break' points in spatial development patterns and sustain the delivery of an alternative regional growth pattern.

\subsection{National Spatial Strategy}

The NSS was published in 2002. It is a 20-year planning framework whose overriding objective is the achievement of balanced regional development, which it defines as, "developing the full potential of each area to contribute to the optimal performance of the State as a whole - economically, socially and environmentally" (Government of Ireland, 2002:11). It describes the existing spatial structure of the island and confirms Dublin as the most important location for economic activity in the island. Critically, the NSS designates a number of additional urban locations as Gateways and also Hubs to be subject to targeted investment $^{14}$, in order to build critical mass of population and economic activity (Figure 4a).

Gateways are defined as locations having a strategic location nationally and relative to their surrounding areas, and providing national-scale social and economic infrastructure, and support services. Hubs are intended to support the national and international role of the Gateways and also energise smaller towns and rural areas within their sphere of influence (Government of Ireland, 2002). The existing Gateways ${ }^{15}$ at Cork, Limerick/Shannon, Waterford and Galway are explained as having "growing strengths" and it is these growing strengths that the NSS seeks to capitalise upon. Furthermore the NSS sets out strategic policy guidance for government investment decisions, and informs regional (sub-national) and local county plans of the national context for spatial planning. This includes all issues of spatial and socio-economic importance such as regional development, rural and urban development, capital infrastructure development, environmental protection and quality of life.

\subsection{National Spatial Strategy Selection Criteria}




\subsection{The National Spatial Strategy and Regional Development}

The NSS outlines a future spatial structure and urban hierarchy, and identifies the distribution of development required to ensure balanced regional development. The NSS suggests that balanced regional development is dependant on the development of nine Gateways and nine Hubs establishing themselves as "engines of growth". These locations are intended to be a focus for population growth and economic activity, and the location for concentrated and targeted investment in infrastructure and services.

The NSS identifies nine Gateways, namely, Dublin, Cork, Limerick/Shannon, Waterford, Galway. Dundalk and Sligo, and Letterkenny/(Derry) and Athlone/Tullamore/Mullingar as linked Gateways. Linked Gateways require two or more towns to work together to promote economic development in their region. In addition, nine new Hubs are identified in the NSS. The Hubs identified are Cavan, Ennis, Kilkenny, Mallow, Monaghan, Tuam and Wexford. Linked Hubs designated are Ballina and Castleber and, Tralee and Killarney, which are linked to promote regional economic development.

The NSS also proposes that the national spatial structure be supported by a national transportation framework. This was detailed further in 2005 with the publication of Transport 21, a ten-year $€ 34.4 \mathrm{bn}$ transport plan. The key national route networks are radial ones linking Dublin with the regions both by road and rail. These routes are to be developed to a high standard of service with the main Dublin interurban route-ways to be developed to motorway standard (Figure 4b). The inter-urban regional rail lines radiating out from Dublin are also being upgraded to improved standards facilitating greater capacity and more regular services.

Important linking corridors include the western road and rail corridor and central spine of road and bus based transport through the midlands. However, despite a recent study (DEHLG and Shannon 
Development, 2006), to date, there is no government commitment to invest significantly in this western road or in the road-based central spine (i.e. dual carriageway or motorway standard), and the western rail corridor will only be partially reopened. Transport 21 was announced by a Government press conference, and details published in a 14-page press release by the Minister for Transport. It contains three speeches and details regarding investment in national road and rail infrastructure, and also an integrated rail system for Dublin.

\subsection{Government Decentralisation Programme}

As one of the first steps in the implementation of the NSS the government officially announced a Decentralisation Programme in Budget 2004. This programme includes the transfer of almost complete Departments of State (Ministries) and other public agencies, including the semi-state sector, to provincial centres and involves the relocation of 10,300 civil and public service jobs to 53 centres in 25 counties including the decentralisation of eight Departments and the Office of Public Works to provincial locations (Figure 5a).

\section{Figure 5. About here}

\subsection{Spatial Economic Analysis of National Spatial Strategy and Decentralisation Programme}

The NSS and Decentralisation Programme, as regional-planning and public-policy interventions, must be evaluated against their primary policy objectives; the achievement of a balanced regional development pattern:

\subsection{Core and Periphery}

Spatial economics suggests that a core-periphery development pattern can only be broken by an intervention that alters the long-term growth trends of spatial development within Ireland, namely the growth and dominance of Dublin and the GDA. As previously noted, the theory would suggest the selection of a limited number of locations as Gateways so as to ensure the necessary concentration of resources and investment.

The NSS has designated a total of 23 urban centres as Gateways and Hubs. Even though there has been a suggestion that larger centres will be prioritised (ICLRD, et al, 2006), without a credible indication of optimum city size (or critical mass) in an Irish context, too many Gateways and Hubs appear to have been selected, removing the possibility of ensuring self-sustaining economic growth in the selected centres. Outside of Dublin, 22 regional urban centres were identified as Gateways or Hubs but only 13 of these were allocated public and civil servant jobs under the Decentralisation Programme, the first step in the implementation of the NSS. Forty other non-NSS regional locations were chosen for $76 \%$ of decentralised 
jobs. As a percentage of the total number of proposed decentralised jobs only $12 \%$ of the total allocation has been identified for relocation to Gateways and $12 \%$ to Hubs (Figure 5a).

Spatial economic analysis would suggests that the failure to allocate most, if not all, of the 10,300 decentralised civil and public servant jobs to a limited number of urban locations designated as Gateways and Hubs in the NSS will undermine the most significant government opportunity to influence and build a critical mass of population and economic activity in a limited number of regional urban centres outside of Dublin (Figure 5b).

We estimate that the decentralisation programme if fully implemented would likely involve relocating up to $3 \%$ of the Dublin population ${ }^{16}$. But, given the long lead-in phase to the programme this will not represent a significant shock to the Dublin economy, which had a population growth rate of $6.1 \%$ between 1996 and 2002. In fact the spread of the decentralisation programme to 53 locations will not give any single Gateway, Hub or provincial location a significant 'first mover advantage' or 'shock' sufficient to alter its current long-term growth path.

Spatial economics suggests that Dublin, under the NSS, will be able to reinforce its current dominant position by extending its core influence at the expense of the periphery as no other single regional Gateway or Hub will gain sufficient additional population or economic activity to challenge the westward growth and increasing dominance of Dublin.

\subsection{Transportation and Regions}

While national transportation systems improve access to markets, radial transportation systems have the potential to reinforce the dominance of the central hub at the expense of peripheral regions. Under the NSS and Transport 21, the radial nature of the national transport network is being reinforced with improvement and development programmes concentrated in a radial manner on the eastern side of the country radiating out from the Dublin 'transport hub' and GDA (Figure 6a). The 'transportation hub concept' first suggested by Krugman (1993) is adapted to the Irish context in Figure 6a. Whilst all regional cities benefit from falling transportation costs, the majority of gains from reductions in transport costs in terms of increasing returns to scale are being 'captured' by Dublin. As most motorways are being 'rolled out' from east to west, Dublin is gradually extending its market capture (commuter destination and consumer spending) and dominance westwards beyond the GDA and into the 'Periphery' along the newly developing motorway corridors as illustrated in Figure 6b. This shows the Average Annual Daily Traffic counts, represented by line thickness, with Dublin at the hub of the national radial road network. Thus it appears that the development of improved transportation and communication linkages between Dublin and the regions is being developed in a manner that ensures a competitive advantage to the Dublin 'transport hub' above all other NSS Gateways and Hubs and highlighted, for example, by a NRA press release "Dublin Moves Closer to Cork and Limerick" following the completion of a section of motorway (NRA, 2004). 
Figure 6. About here

According to spatial economic models, in order to create a sustainable 'lock-in effect' at a regional urban centre, sometimes it is necessary to generate a temporary barrier to trade, of sorts, and the use of planning intervention through national spatial planning and policy is one potential approach. The phasing of motorway development to favour the developing region would appear to offer peripheral regions an opportunity to capture the market prior to established development centres. Spatial economics would suggest that the development of the national radial motorway network in a west to east phasing may give the newly established Gateways and Hubs an opportunity to capture an extended market before the GDA extends its productive resources into the region.

There are also levels of inter-urban traffic along non-Dublin origin/destination routeways, which have similar levels AADT to sections of the Dublin inter-urban routeways currently designated for motorway standard as illustrated in Figure 5. Spatial economics would suggest that consideration be given to development of a motorway standard routeway to link the main Irish regional cities (for example, Galway Limerick - Cork - Waterford) to achieve the government stated objective of balanced regional development.

\subsection{Urban Concentration: Trade and Power Relations}

The factors that underlie Ireland's spatial development patterns, namely: a small country with a low population density; a highly open free-trade economy; and, a highly-centralised governance structure, all induce agglomeration and urban concentration. Spatial economic theory suggests that without significant national spatial policy intervention, Ireland's regional development trends will continue to develop along current patterns concentrating population and economic activity in Dublin, the primate city, and the surrounding commuter belt of the GDA.

However the theory would also suggest that without a more targeted programme of decentralisation into a limited number of development centres the NSS will not reduce the dominance that Dublin currently possesses in the current national urban system. The national spread of the Decentralisation Programme will not give any single location a significant 'first mover' advantage. Indeed a significant effort does not appear to have been made to capitalise on potential returns to scale and build synergy between decentralising departments and the specialist functions of chosen locations for decentralisation (Bannon, 2004). The consequence may be the potential loss of spillover effects previously experienced between Ministries agglomerated in Dublin.

Overall it is questionable how decentralisation will benefit the nation as a whole through the loss of agglomeration economies, apart from the local small-scale dispersed gains for the 53 individual chosen 
locations. Indeed, despite the proposal to decentralise 10,300 jobs, no devolution of decision-making power is included in the programme and all policy decisions will still be made in Dublin retaining the political centralisation of decision-making and missing an opportunity to tackle the centralised Irish governance structure that also reinforces Dublin's dominance (Bannon, 2004).

Given the extent of the proposed dispersal of decentralised jobs, the potential gain to the periphery of building up a limited number of other urban centres or a single alternative competitive city benefiting from significant multiplier effects may be irretrievably lost. Ultimately the policy effectiveness of the NSS, i.e. the ability of policy to achieve its stated objectives, may be undermined.

\subsection{Evaluation of the Application of Spatial Economic Theory to National Spatial Planning}

Whilst recent contributions from economics, in particular regional economics, provide a theoretical basis for economic analysis of international trade, mainstream economics traditionally neglected spatial analysis of economies. The spatial economic analysis literature, in particular that contributed to by NEG, has tended to focus on supra-national regions, with much of its focus on theoretical analysis. However there are substantial differences in economic performance within nations and across sub-national regions, requiring more detailed analysis at a sub-national scale. We took the existing elements of spatial economic analysis that are most relevant to the sub-national level and national spatial planning context and further advanced these theories by emphasising the importance of the issues of power relations and also the important role that path-dependence plays in determining the spatial structure of national economies. This paper has applied the theory to the nation-state level using a case study of Ireland and has examined its usefulness as a theoretical basis for national spatial planning.

From the analysis, it appears that what would be predicted by the theoretical model is borne out in an assessment of the spatial patterns of development in Ireland with a clear core-periphery having emerged within the nation. The model, therefore, is of assistance in the analysis of spatial development patterns and trends. In addition, it provides a good theoretical framework for policy interventions. Nevertheless, the model is just a prediction of the likely success or otherwise of such interventions. While the findings of the model seem plausible and, therefore, suggest that spatial economic models can be of significant use in national spatial planning, further ex post empirical research would be required to test their predictions.

Whilst we have shown that the economic predictions in terms of national spatial trends are borne out by spatial economic models, these same models do not adequately evaluate social and environmental policy objectives. A weakness of the spatial economic models is their emphasis on income and population and less direct consideration of non-market goods and services. The concept of sustainable development is now at the heart of spatial planning policy and the overall objective of policy interventions must surely be the maintenance or, ideally, the improvement of quality of life. The primary objective of the Irish NSS is to deliver more balanced regional development, and to develop the full potential of each area to contribute to 
the optimal performance of the State as a whole - economically, socially and environmentally (Government of Ireland, 2002) ${ }^{17}$. The latter are compelling objectives. However measuring 'potential' in relation to maximizing the capacity of social and environmental resources is difficult. Nevertheless, the NSS suggests that, by using the framework it provides, not only will a better balance of economic development be achieved, but also social and physical development and population growth will be better balanced between regions. In particular, there is a strong focus on quality of life with much emphasis promoting policy measure to reduce commuting and the environmental damage resulting from large dislocations between where people live, work and socialise. Although we did point out the existence of significant regional disparities in terms of quality of life within Ireland in our analysis, in particular relating to localised environmental quality and life satisfaction, the predominant analytical approach of the model is based on economic attributes with a strong emphasis on income measures. Therefore, in order to improve their capacity to assist in national spatial policymaking further advances in the development of spatial economic models require greater focus on the social and environmental attributes of quality of life that affect regional well-being.

A further point regarding the models is that they do not take into account the complexity of the policy formation process. Any national spatial strategy is a political statement that requires sufficient political support along with the support of key actors, not least the electorate. Political imperatives often result in second-best or third-best solutions in many cases and the nature of the political system will influence the likelihood of success of a national spatial plan.

\subsection{Conclusion}

Whilst there is a substantial amount of published literature devoted to the subject of spatial economics, very little attention has been given to its public policy applications or indeed to spatial planning policy. This is surprising considering the number of national spatial planning policy frameworks adopted by national governments in Europe over recent years but lacking in any clear theoretical basis from a spatial economics perspective. Therefore this paper had two principal objectives: firstly, to develop a spatial economic theory relevant to national spatial planning, and secondly, to examine its performance as a theoretical basis for national spatial planning policy.

Based on spatial economic theory and analysis, the paper provides an analytical framework to further understanding of the factors that underlie the spatial distribution of population and economic activity and their implications for national spatial planning. In particular, the importance of increasing returns to scale as a key determinant of the degree of spatial differentiation between locations is highlighted, and given further emphasis by the development of 'transportation hubs' at specific locations that play a major role in city formation, and thereafter, regional development. The importance of the location of decision making power and the issue of path dependence are also given greater status when applying spatial economic theory to national spatial planning. 


\section{Acknowledgements}

We would like to thank Paula Russell, Colm McCarthy, Peter Neary, Declan Redmond, Brendan Walsh, Brendan Williams, participants at the Regional Studies Association Conference (Angers, April 2004) and the RTPI Planning and Development Research Conference (Aberdeen, 2004), the editor of Regional Studies, and three anonymous referees. The assistance of Daniel McInerney with GIS is gratefully acknowledged, as is financial support from the EPA ERTDI Programme. Any conclusions and/or errors are the responsibility of the authors. 


\title{
Endnotes
}

\begin{abstract}
${ }^{1}$ The most significant contributor to spatial economics literature, and the main proponent of the NEG, has been Paul Krugman who published the seminal publications, Geography and Trade (1991a) and Increasing Returns and Economic Geography (1991b), and a large number of other related publications (see for example, Krugman, 1991c, 1993, 1994, 1996, 1998a, 1998b, 1999, 2001). A number of other economists have also made important contributions, for example, Evans, Fingleton, Fujita, McCann, Mori, Neary, Ottaviano, Puga, Thisse, Venables, and Wenban-Smith. A joint publication of Fujita, Krugman and Venables (2001), The Spatial Economy, has brought together much of the theoretical work within the field to date as does Brakman et al. (2001), and Baldwin et al. (2003).
\end{abstract}

${ }^{2}$ For more in depth details about the difference between traditional economic geography and NEG, see Krugman (1998b) "What's New About The New Economic Geography?"

${ }^{3}$ See references: N.I. Department for Regional Development, 2001; Welsh Assembly Government, 2004; Scottish Executive 2004; Dutch Ministry of Housing, Spatial Planning and the Environment, 2001; Danish Ministry of the Environment, 2003.

${ }^{4}$ Regional development theory, urban economics, regional science and economic geography

${ }^{5}$ Also referred to as sub-national regional planning.

${ }^{6}$ See Clinch et al. (2002) for further details.

${ }^{6}$ For example, Davis and Weinstein (2002) showed that Nagasaki and Hiroshima, the eight and twelfth largest cities in Japan who lost $8.5 \%$ and $20.8 \%$ of their city populations respectively in World War II, had both recovered their relative size (in terms of population) by 1960, and controlling for pre-war growth trends, both had entirely reversed the economic impact by 1965 .

\begin{abstract}
${ }^{7}$ The National Development Plan 2000 - 2006 (2000) was another important initiative published prior to the NSS. It is a multiannual investment programme and development strategy that sets forth the governments investment commitments in the various sectors of the economy. It involves an investment of over $€ 52$ billion (1999 prices) in health services, social housing, education,
\end{abstract} transport, rural development, industry, water and waste services.

${ }^{8}$ The preparation of the NSS was informed by a number of research reports commissioned by the spatial planning unit of the Department (Ministry) of the Environment (see www.irishspatialstrategy.ie). These sought to establish emerging trends in all aspects of the national spatial structure and to establish the consequence of a continuance of those trends. Research reports commissioned were: Coastal Zone Management; Enterprise, Employment and Productivity Trends; Irish Rural Structure and Gaeltacht Areas; Sustainable Transport Demand; Transport Corridors in Europe; Transport and Regional Development; Extensive and Intensive Rural Landuses; The Irish Urban System and it's Dynamics; Rural Enterprise; Population, Labour Force and Housing Demand Projections; Rural Resource Potential and Management Issues; Information Technology Infrastructure; The Role of Dublin in Europe; Rural and Urban Roles.

\footnotetext{
${ }^{9}$ For a review of the evolution and development of regional policy in Ireland see Bannon and Lombard (1996). For a discussion of recent regional development trends see O'Leary (2003).
} 
${ }^{10}$ Gross Value Added (GVA) at a factor cost is a measure of the value of goods and services produced in a region priced at the value which the producers receive minus any taxes payable and plus all subsidies (Boyle et al, 1999:7). Where an index of GVA per capita is created and comparison made relative to the national average of 100 , this index shows substantial regional variation. GVA in the South and East (NUTS II, including Dublin) was 111 compared with 69 in the Borders, Midlands and West region (NUTS II, also referred to as BMW region). At a sub-regional scale Dublin (NUTS III) has a GVA measured at 129. The Border Midland West (BMW) and South \& East (S\&E) Regional Assemblies are NUTS II regions and are comprised of the 8 NUTS III regions.

${ }^{11}$ In industrial sectors, the East and Southwest have the highest productivity levels reflective of the high concentrations in Cork and Dublin, which contrast with the relatively low productivity levels in the BMW region. In terms of services the East has the largest and still growing level of services provision. Dublin has developed as a location for internationally traded services with $77 \%$ of the national employment in this sector (Government of Ireland, 2002:14).

${ }^{12}$ For example, for even relatively small public infrastructure projects, each stage of the local government procurement process must be approved by the Department of the Environment, Heritage and Local Government.

${ }^{13}$ This equals to $111.2 \%$ and $89.2 \%$ of planned expenditure in the S\&E and BMW regions respectively.

${ }^{14}$ The NSS outlines the main characteristics of Gateways and Hubs (Government of Ireland, 2002:40).

${ }^{15}$ Gateways previously designated under the NDP.

${ }^{16}$ Assuming an average household size of three (CSO Census 2002), there could be up to 31,000 people directly affected by the decentralisation programme, or $3 \%$ of the Dublin population.

${ }^{17}$ See Clinch (2002) for further details on the relationship between economic growth and sustainability. 


\section{References}

Armstrong, H. and Taylor, J., (2000), Regional Economics and Policy, Third Edition, Blackwell, Oxford.

Bannon, M.J., (2004), "The Proposed Arrangements of Consideration of Public Service Decentralisation”, Presentation to the Oireachtas Joint Committee on Finance and the Public Service, July 24, Dublin.

Bannon, M.J. and Lombard, M., (1996), "Evolution of Regional Policy in Ireland" in Shannon Development Regional Policy, A Report by a Policy Advisory Group to Forfas, pp. 57-83, Shannon Development, Shannon.

Bond, D. and Devine, P., (1991), “The Role of Geographic Information Systems in Survey Analysis”, The Statistician, Vol. 40(2), pp. 209-216

Boyle, G.E., McCarthy, T., and Walsh, J., (1999), "Regional Income Differentials and the Issue of Regional Equalisation in Ireland", Journal of the Statistical and Social Inquiry Society of Ireland, Vol. XXVIII Part 1, pp. 155-198.

Baldwin, R., Forslid, R., Martin, P., Ottaviano, G., and Robert-Nicoud, F., (2003), Economic Geography and Public Policy, Princeton University Press, Princeton, New Jersey.

Brakman, S., Garretsen, H., and van Marrewick, C., (2001), An Introduction to Geographical Economics, Cambridge University Press, Cambridge.

Clinch, J.P., Convery, F. and Walsh, B., (2002), After the Celtic Tiger: Challenges Ahead, O'Brien Press, Dublin

Clinch, J.P. (2002). "Reconciling Rapid Economic Growth and Environmental Sustainability in Ireland", Journal of the Statistical and Social Inquiry Society of Ireland, Vol. XXX, pp. 159-218

Clinch J.P., Brereton, F and Ferreira, S., (2007) "Happiness, Geography and the Environment", Ecological Economics, forthcoming.

Convery, F.J., McInerney, D., Sokol, M. and Stafford, P., (2006), "Organising Space in a Dynamic Economy: Insights for Policy from the Irish Experience”, Built Environment, Vol. 32(2), pp. 172-183.

CSO (2002), Census Data: Volume 1, Population Classified by Area, The Stationary Office, Dublin.

CSO (2003), Statistics of Port Traffic, Central Statistics Office, Dublin. 
CSO (2005), Regional Population Projections 2006 - 2021, Central Statistics Office, Dublin.

Danish Ministry of the Environment, 2003, Balanced Development in Denmark - What Needs to be Done? National Spatial Planning Report, Ministry of the Environment, Copenhagen.

Davis, D.R. and Weinstein, D.E., (2002), "Bones, Bombs and Break Points: The Geography of Economic Activity", The American Economic Review, Vol. 92(5), pp. 1269-1289.

Davoudi, S. and Wishardt, M., (2005), "The Polycentric Turn in the Irish Spatial Strategy", Built Environment, Vol. 31(2), pp. 122-132.

DEHLG and Shannon Development (2006), Atlantic Gatways Initiative: Achieving Critical Mass, Spatial Planning Unit, Department of the Environment, Heritage and Local Government, Dublin.

Department of Finance (2003), Financial Statement of the Minister for Finance Mr. Charlie McCreevy T.D., Budget 2004, December 3, Department of Finance, Dublin.

Department of Transport, (2005), Transport 21, Press Release, November 1, Department of Transport, Dublin.

DKM Economic Consultants (2003), Review of Air Services Supported by the Essential Air Services Programme, report prepared for the Department of Transport, Dublin.

DoELG (2000) Enterprise, Employment and Productivity Trends, Spatial Planning Unit, Department of the Environment and Local Government, Dublin.

Dutch Ministry of Housing, Spatial Planning and the Environment, (2001), Making Space, Sharing Space: Fifth National Policy Document on Spatial Planning for Netherlands 2000 - 2020, Ministry of Housing, Spatial Planning and the Environment, The Hague.

Evans, A., (2003), "The Development of Urban Economics in the Twentieth Century", Regional Studies, Vol. 37(5), pp. 521-529.

Fingleton, B., (2000), "Spatial Econometrics, Economic Geography, Dynamics and Equilibrium: A 'Third Way", Environmental and Planning A, Vol. 32, pp. 1481-1498.

Fingleton, B., (2003), "Externalities, Economic Geography, and Spatial Econometrics: Conceptual and Modelling Developments", International Regional Science Review, Vol. 26(2), pp. 197-207. 
Friedmann, J., (2001), “Regional Development and Planning: The Story of Collaboration”, International Regional Science Review, Vol. 24(3), pp. 386-395.

Fujita, M. and Krugman (2004), "The New Economic Geography: Past, Present and the Future”, Papers in Regional Science, Vol. 83, pp. 139-164.

Fujita, M., Krugman, P. and Mori, T., (1999), "On the Evolution of Hierarchical Urban Systems", European Economic Review, Vol. 43, pp. 209-251.

Fujita, M. and Mori, T., (1996), "The Role of Ports in the Making of Major Cities: Self Agglomeration and Hub Effect", Journal of Development Economics, Vol. 49, pp. 93-120.

Fujita, M., Krugman, P. and Venables, A.J., (2001), The Spatial Economy - Cities, Regions and International Trade, M.I.T. Press, Cambridge, Massachusetts.

Gkartzios, M. and Scott, M. (2005), "Urban-generated rural housing and evidence of counterurbanisation in the Dublin city-region", in (eds.) Scott, M. and Moore, N., 2005, Renewing Urban Communities: Environment, Citizenship and Sustainability in Ireland, Ashgate, Aldershot.

Goodall, B., (1972), The Economics of Urban Areas, Pergamon Press, Oxford.

Goodall, B., (1987), The Penguin Dictionary Of Human Geography, Penguin, London.

Goodbody Economic Consultants, (2000), Transport Demand: NSS Research Report, report prepared for the Department of the Environment and Local Government, Dublin.

Goodchild, M.F. and Haining, R.P., (2004), "GIS and Spatial Data Analysis: Converging Perspectives", Papers in Regional Science, Vol. 83(1), pp. 363-385

Government of Ireland, (2000), National Development Plan 2000 - 2006, Government Stationery Office, Dublin.

Government of Ireland, (2002), The National Spatial Strategy 2002 - 2020, People, Places and Potential, The Stationery Office, Dublin.

ICLRD, Brady Shipman Martin, and Fitzpatrick Associates Economic Consultants (2006), Implementing the NSS: Gateway Investment Priorities Study, report prepared for Forfas and the Department of the Environment, Heritage and Local Government, Dublin. 
Isserman, A.M., (1995), "The History, Status, and Future of Regional Science: An American Perspective”, International Regional Science Review, Vol. 17(3), pp. 249-296.

Indecon International Economic Consultants, (2003), Mid-Term Evaluation of the Economic and Social Infrastructural Operational Programme, report prepared for the Department of Transport, Dublin.

Krugman, P., (1991a), Geography and Trade, Leuven University Press and M.I.T. Press, Leuven and Cambridge, Massachusetts.

Krugman, P., (1991b), "Increasing Returns and Economic Geography", Journal of Political Economy, Vol. 99(3), pp. 483-499.

Krugman, P., (1993), "The Hub Effect: or Threeness in Interregional Trade”, in Helpman, E., Neary, J. P., and Wilfred, J.E., 1993, Theory, Policy and Dynamics in International Trade, pp. 29-37, Cambridge University Press, Cambridge.

Krugman, P., (1994), “Complex Landscapes in Economic Geography”, AEA Papers and Proceedings, Vol. 84(2), pp. 412-416.

Krugman, P., (1996), "Urban Concentration: The Role of Increasing Returns and Transport Costs", International Regional Science Review, Vol. 19(1), pp. 5-30.

Krugman, P., (1998a), "Space: The Final Frontier", Journal of Economic Perspectives, Vol. 12, pp. 161174.

Krugman, P., (1998b), "What's New About The New Economic Geography?", Oxford Review of Economic Policy, Vol. 14(2), pp. 7-17.

Krugman, P., (1999), "The Role of Geography in Development", International Regional Science Review, Vol. 22, pp. 142-161.

Krugman, P. and Elizondo, R.L., (1996), “Trade Policy and the Third World Metropolis”, Journal of Development Economics, Vol. 49, pp. 137-150.

Krugman, P. and Venables, A.J., (1995), "Globalisation and the Inequality of Nations", The Quarterly Journal of Economics, Vol. CX(4), pp. 857-880. 
Krugman, P. and Venables, A.J., (1996), "Integration, Specialisation, and Adjustment", European Economic Review, Vol. 40, pp. 959-967.

Martin, R., (1999a), “The New 'Geographical Turn' in Economics: Some Critical Reflections”, Cambridge Journal of Economics, Vol. 23, pp. 65-91.

Martin, R., (1999b), “Editorial: The 'New Economic Geography': Challenge or Irrelevance?”, Transactions of the Institute of British Geographers, New Series, Vol. 24(4), pp. 387-391.

McCann, P., (1995), "Rethinking the Economics of Location and Agglomeration", Urban Studies, Vol. 32(3), pp. 563-577.

McCann, P., (2001), Urban and Regional Economics, Oxford University Press, Oxford.

Morgenroth, E., (2001), Analysis of the Economic, Employment and Social Profile of the Greater Dublin Region, E.S.R.I., Dublin.

Myrdal, G., (1957), Economic Theory and Underdeveloped Regions, Gerald Duckworth and Co. Publishers, London.

Neary, J.P., (2001), "Of Hype and Hyperbolas: Introducing the New Economic Geography”, Journal of Economic Literature, Vol. XXXIX, pp. 536-561.

Neary, J.P., (2006), "Book Review of: Economic Geography and Public Policy, by Baldwin, R., Forslid, R., Martin, P., Ottaviano, G., and Robert-Nicoud, F., (2003)", forthcoming in Journal of International Economics.

Northern Ireland Department for Regional Development, (2001), Shaping Our Future: Regional Development Strategy for Northern Ireland 2025, Corporate Document Services, Belfast

NRA, (2003), “Transport Policies”, www.nra.ie/National/DevelopmentPlan/TransportPolicies, National Roads Authority, Dublin.

NRA, (2004), "Dublin Moves Closer to Cork and Limerick", Press Release, November 8, National Roads Authority, Dublin.

NRA, (2004), National Roads and AADT Flows, unpublished data.

O'Leary, E., (2003), (Ed.), Irish Regional Development: A New Agenda, Liffey Press, Dublin. 
O’Leary, E., (2002), “Sources of Regional Divergence in the Celtic Tiger: Policy Responses”, Journal of the Statistical and Social Inquiry Society of Ireland, Vol. XXXII, pp. 1-32.

Ottaviano, G.I.P. and Puga, D., (1997), "Agglomeration in the Global Economy: A Survey of the 'New Economic Geography"”, Centre for Economic Performance Discussion Paper No. 356, CEPR, London.

Ottaviano, G.I.P, (2003), "Regional Policy in the Global Economy: Insights from New Economy Geography", Regional Studies, Vol. 37(6), pp. 665-673.

Perroux, F., (1950), “Economic Space: Theory and Applications”, in Friedmann, J. and Alonso, W., 1964, Regional Development and Planning, pp. 21-36, M.I.T. Press, Cambridge, Massachusetts.

Puga, D., (1999), “The Rise and Fall of Regional Inequalities”, European Economic Review, Vol. 43, pp. 303-334.

Ricci, L.A., (1999), "Economic Geography and Comparative Advantage: Agglomeration versus Specialisation", European Economic Review, Vol. 43, pp. 357-377.

Scottish Executive, (2004), National Planning Framework for Scotland, Scottish Executive, Edinburgh.

Thisse, J.F., (1993), “Oligopoly And The Polarisation Of Space”, European Economic Review, Vol. 37, pp. 299-307.

Venables A.J., (1996), "Equilibrium Locations of Vertically Linked Industries”, International Economic Review, Vol. 37(2), pp. 341-359.

Venables, A.J., (1998), "The Assessment: Trade and Location", Oxford Review of Economic Policy, Vol. 14 , pp. $1-5$.

Walsh, B.M., (2000), "Urbanisation and the Regional Distribution of Population in Post-Famine Ireland", Journal of European Economic History, Spring, 29(1), pp.109-130.

Walsh, B.M., (2006), "Labour Market Adjustment in the Irish Regions: 1988 - 2005”, Quarterly Economic Commentary, Autumn, pp. 80-89.

Walsh, J., (2000), “Dynamic Regional Development in the EU Periphery: Ireland in the 1990s”, in (eds) Shaw, D., Roberts, P. and Walsh, J., 2003, Regional Planning and Development in Europe, pp. 117-137, Ashgate, Aldershot. 
Welsh Assembly Government, (2004), People, Places, Futures - Wales Spatial Plan, Welsh Assembly, Cardiff.

Wenban-Smith, H.B., (2004), "Transport Costs and Urban Development", Transport, 157 Issue TR2, pp. 89-97.

Wong, C., (2002), "Is There a Need for a Fully Integrated Spatial Planning Framework for the United Kingdom?", Planning Theory and Practice, Vol. 3 (3), pp. 277-300.

Wu, Y.-H., Miller, H.J. and Hung, M.-C., (2001), “A GIS-Based Decision Support System for Analysis of Route Choice in Congested Urban Road Networks," Journal of Geographical Systems, Vol. 3(1), pp. 3-24. 
Table 1. Centripetal and Centrifugal Forces

\begin{tabular}{|l|l|}
\hline Centripetal Forces & Centrifugal Forces \\
\hline Linkages / Market Size Effects & Immobile Factors \\
Thick Labour Markets & Land Rents \\
Pure External Economies & Pure External Diseconomies \\
High Level of Free Trade & Low Level of Free Trade \\
\hline
\end{tabular}

Source: Modified from Krugman (1998b) 
Figure 1. Core and Periphery (By County): Disposable Income Distribution (a); Disposable Income Density (€ per sq km) (b); Population Density Rates (c); Population Growth Rates (d).
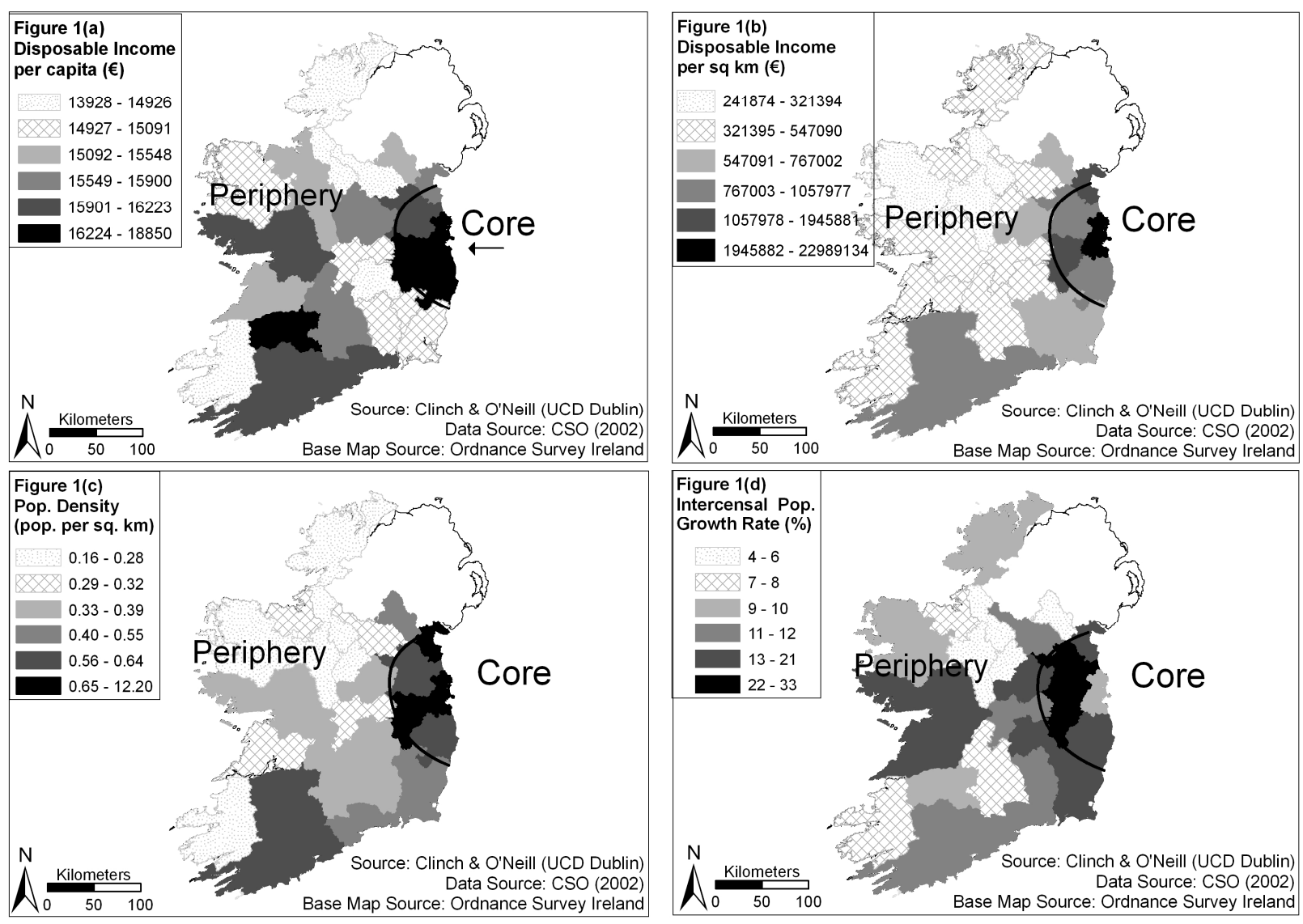
Figure 2. Airport Passenger Numbers (a); Inter-Regional Air Routes (b).

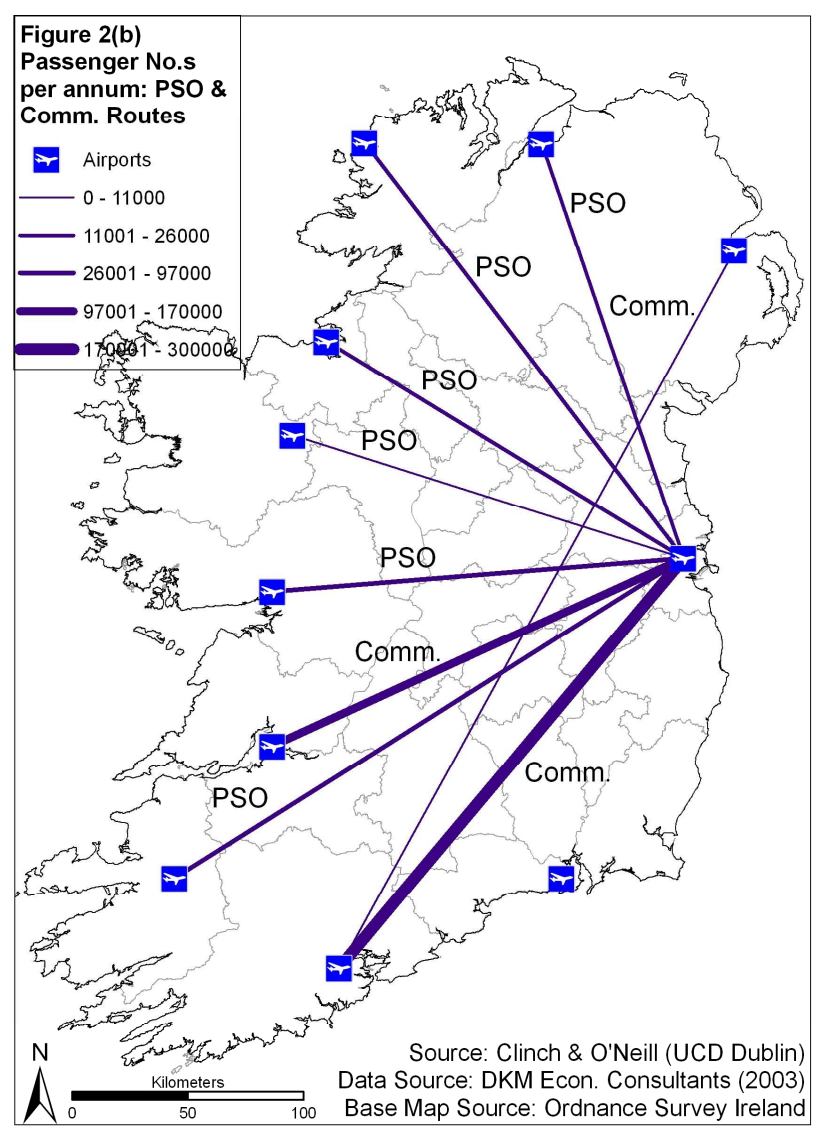


Figure 3. Port Freight Gross Tonnage (a); Top 10 County-To-County Rail Passenger Numbers (b).
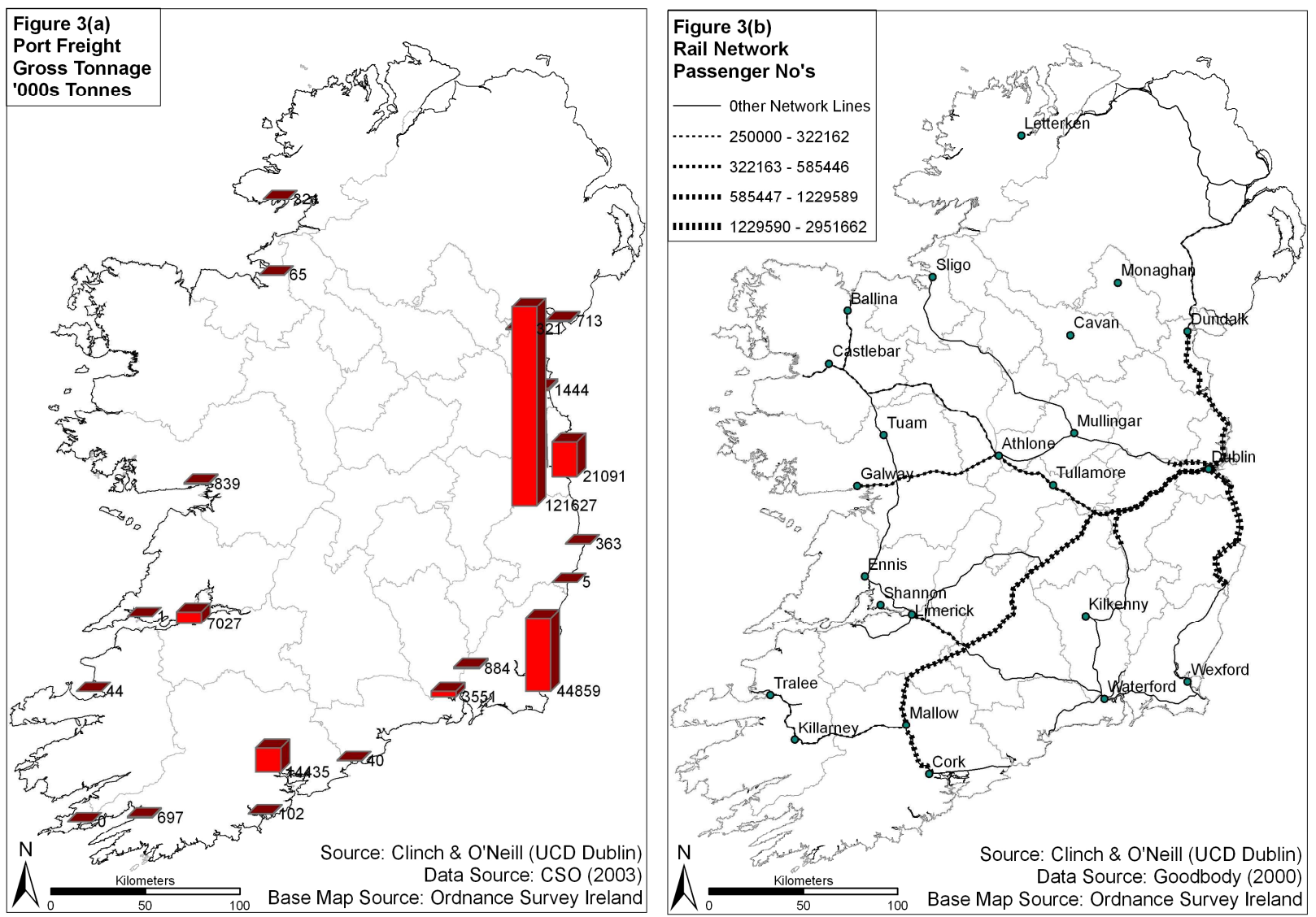
Figure 4. National Primary Road Network by Annual Average Daily Traffic (AADT) Count \& NSS Locations (a); Transport 21 National Roads Plan (b).
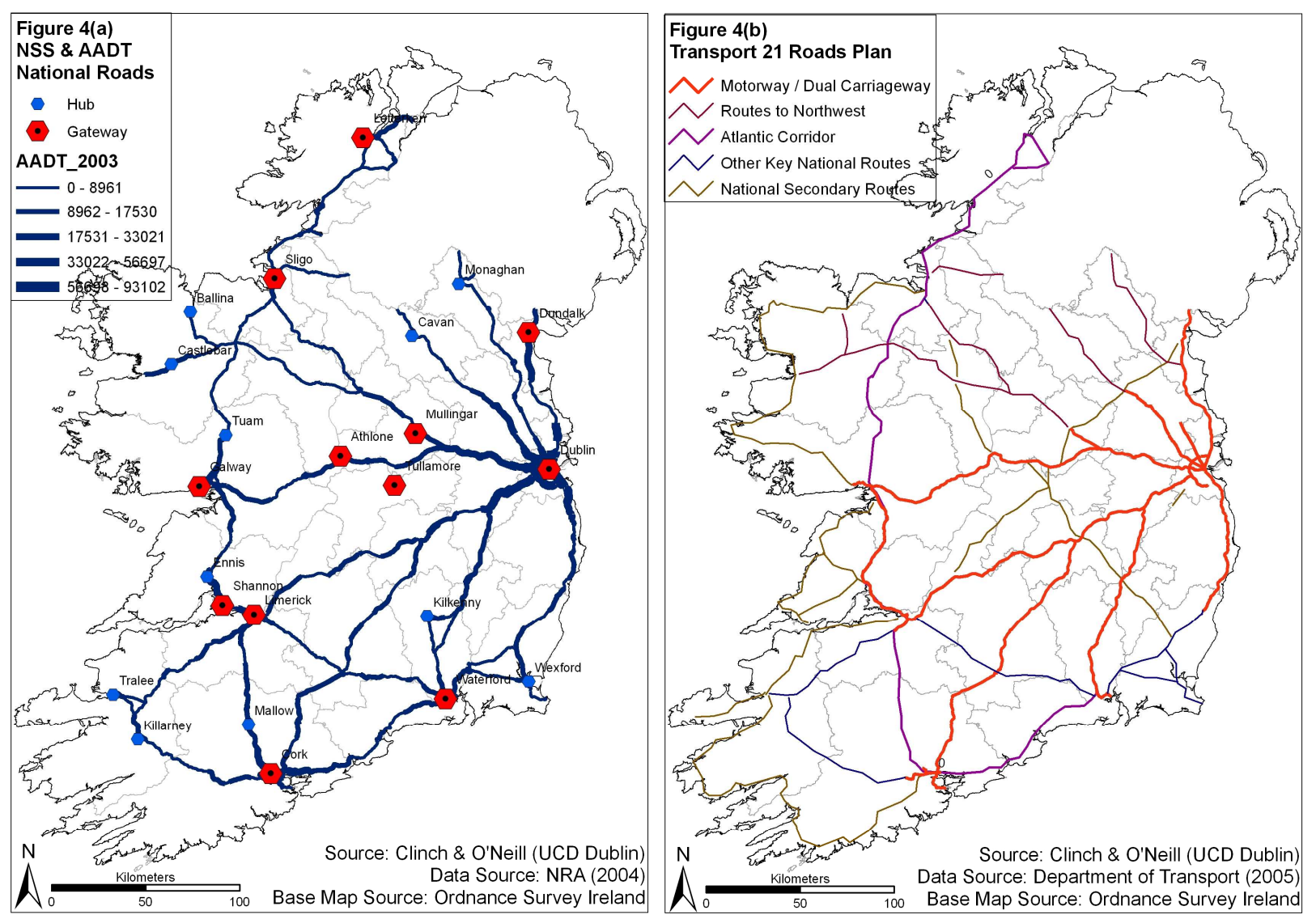
Figure 5. Decentralisation Locations and Percentage Breakdown of Jobs by Location (a); Decentralisation Programme and NSS Locations.
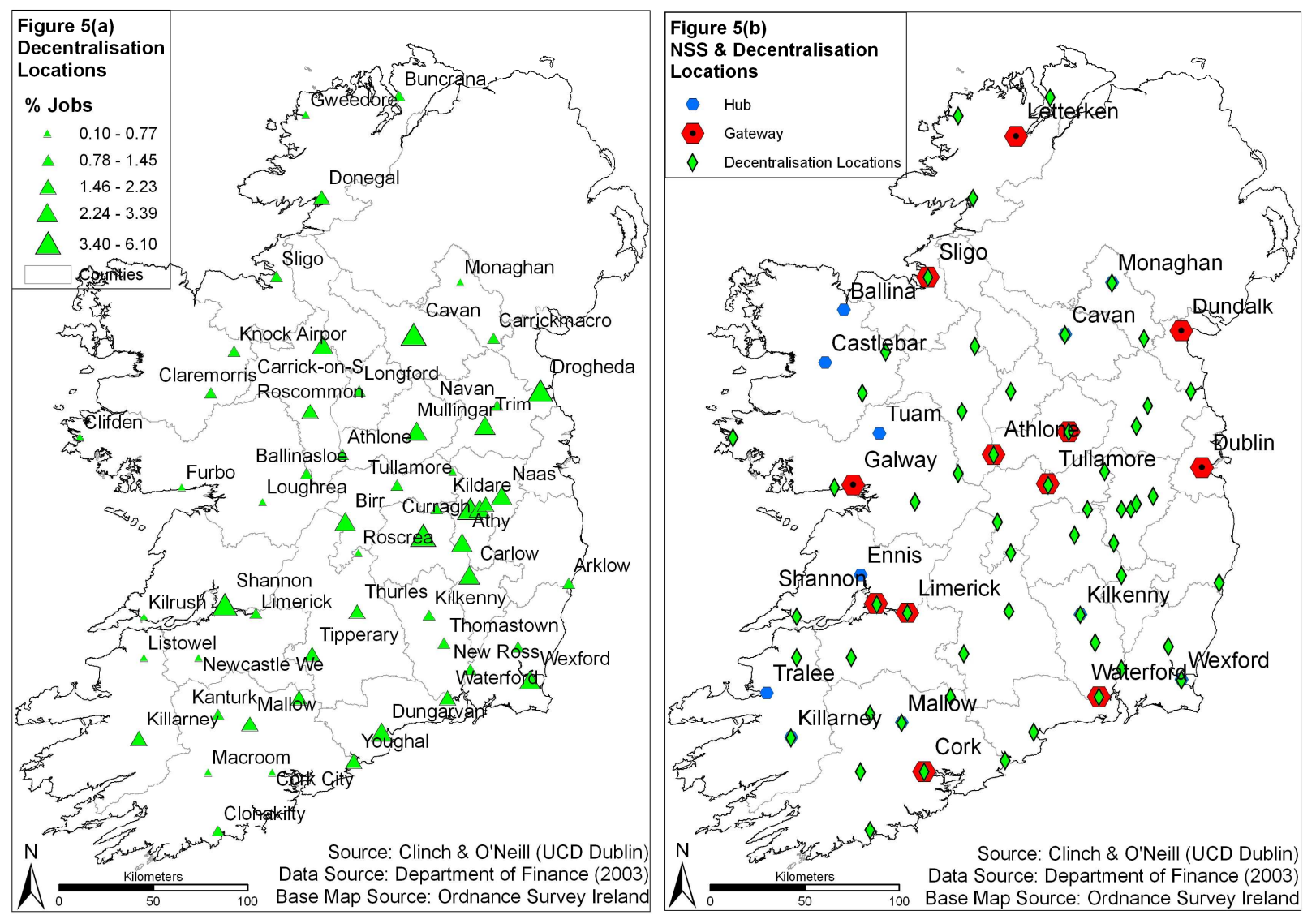
Figure 6. Dublin 'Transport Hub' and Inter Urban Transportation Costs (a); Dublin's Captured Markets represented by AADT (b).
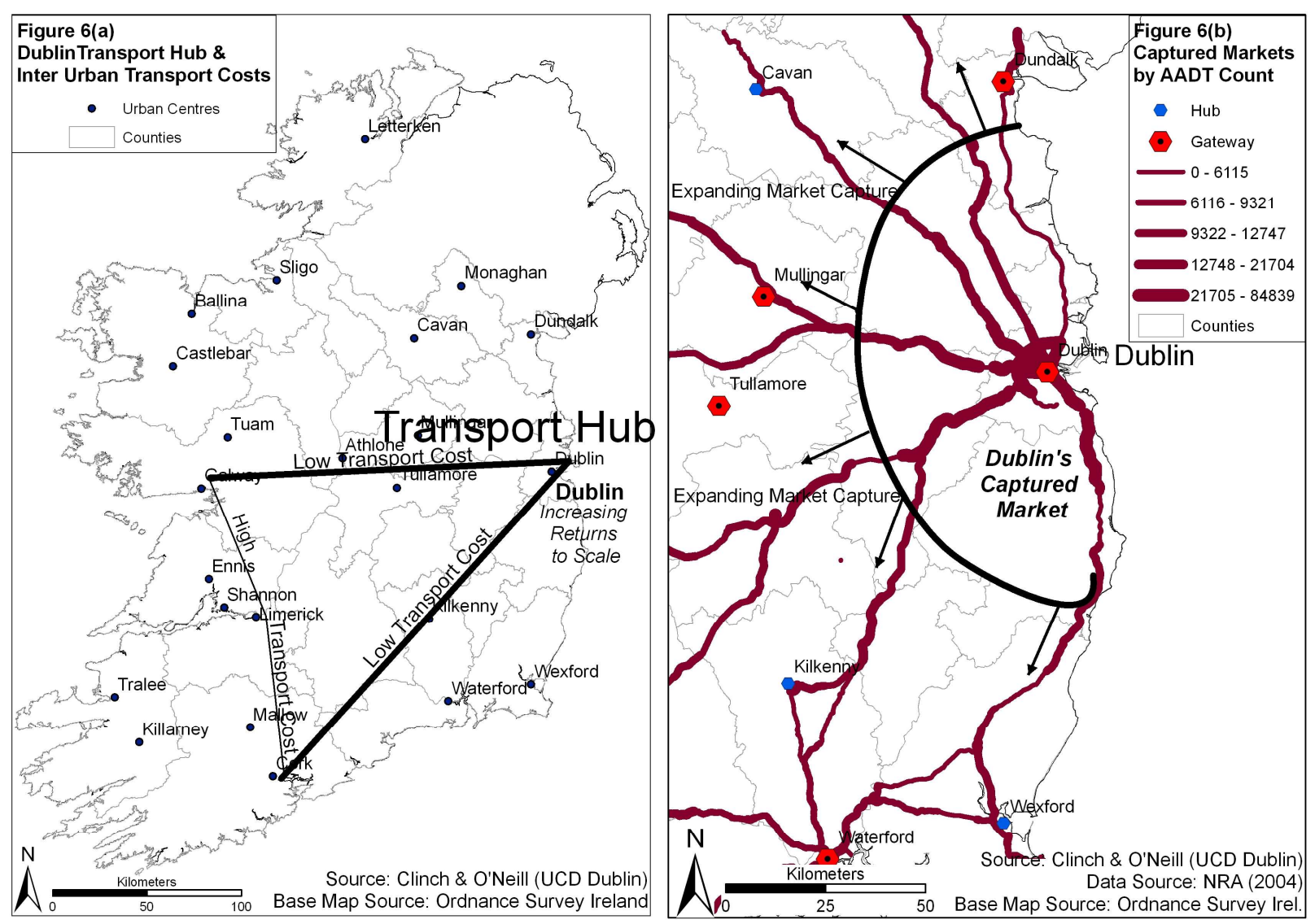